Poznańskie Studia Teologiczne 27(2013), s. 117-138.

Janusz Nawrot

Uniwersytet im. Adama Mickiewicza w Poznaniu

Wydział Teologiczny

\title{
Jaką rolę odgrywają starsi Izraela w tekstach przedstawiających epokę Mojżesza?
}

\section{Wstęp}

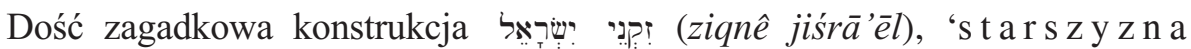
I z rae la', obecna jest w licznych tekstach starotestamentowych ${ }^{1}$. By nie rozszerzać zbytnio prezentowanego materiału, ograniczymy się jedynie do tekstów odnoszących się do czasów wyjścia Izraelitów z niewoli egipskiej i Jozuego, ponieważ opisana w nich relacja $\mathrm{s}$ ta r s z y ch do poszczególnych przywódców najlepiej ukazuje specyfikę tej grupy społecznej. Nie kierują oni bowiem samodzielnie resztą ludu, lecz są posłusznymi wykonawcami poleceń z góry i w tej właśnie roli ich prezentacja biblijna wypada najlepiej. Można natomiast zauważyć, że tam, gdzie wodza zabrakło, stars zy zn a generalnie nie spełniła pokładanych w niej oczekiwań ${ }^{2}$ W passusach, które zawierają wiadomości o tych ludziach, tworzą oni pewną grupę społeczną, odróżnioną od reszty ludu, uprzywilejowaną i stanowiąca jakby pierwszy jego szereg. Nie mają oczywiście żadnych święceń ani nie są predestynowani do tego, by samodzielnie pełnić jakiekolwiek funkcje, zwłaszcza natury sakralnej. Są jednak potrzebni przede wszystkim w komunikacji między wybranymi przez Boga na przywódców kierujących życiem religijnym społeczności wodzami i prorokami a resztą ludu, od którego wymagał On jedynie posłuszeństwa wobec przekazywanych poleceń.

\footnotetext{
${ }^{1}$ Obiektem badań jest tu jedynie ta właśnie konstrukcja literacka. Stary Testament zna jeszcze

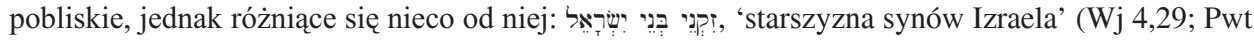
31,9; Sdz 11,5), זקרנִים, 'starsi' (Pwt 25,7.9; Joz 24,31; Sdz 2,7; 1 Krl 12,6.8.13; 20,8; 21,8.11; 2 Krl

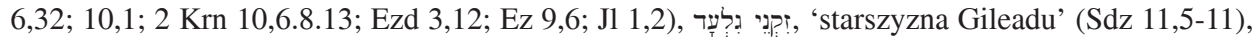

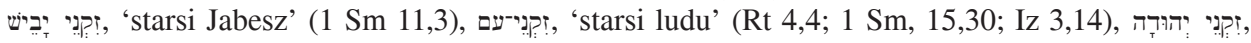

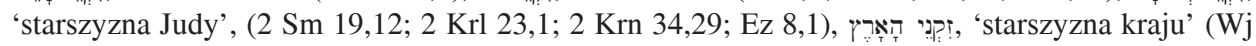

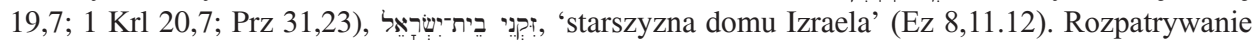
ich po kolei wydłużyłoby niezmiernie treść artykułu, tym bardziej że nie wnoszą one niczego szczególnie nowatorskiego w rozumienie sensu konstrukcji podstawowej. Całość omawiająca owe zwroty zamieszczona jest skrótowo w Theological Dictionary of the Old Testament, vol. IV, s. 122-131. Ponadto występują oni jeszcze w późniejszych epokach państwa, por. $1 \mathrm{Krl} 8$,1.3; $1 \mathrm{Krn}$ 15,25; 2 Krn 5,2.4.

${ }^{2}$ Por. m.in. 1 Sm 4,3; 8,4; 2 Sm 17,4.15; Ez 20,3.
} 
Poniższy artykuł jest próbą określenia roli, jaką odgrywali s t a r s i społeczności w jej dziejach. Ponieważ punktem wyjścia jest tekst biblijny, nie zajmiemy się rozpatrywaniem kwestii należących do metody historyczno-krytycznej, by nie zagłębiać się zbytnio w trudne relacje między poszczególnymi tradycjami komponującymi relacjonowane perykopy ${ }^{3}$. Nie jest bowiem pierwszorzędnym zadaniem autora artykułu odkrywanie historycznych kontekstów funkcjonowania starożytnych Izraelitów. Podejmiemy natomiast refleksję teologiczną tak, jak prezentują ich autorzy natchnieni wyznaczający im specyficzną rolę w ciągu dziejów narodu wybranego. Starszyzna zostaje zaprezentowana jako pomost między wodzami a ludem.

\section{Przedstawiciele ludu}

To pierwsza i najważniejsza z ról, jakie starszyzna odgrywała w lokalnej społeczności. Na jej podstawie można ukazać kilka charakterystycznych cech tej grupy społecznej i wynikające z tego postawy zarówno wobec przywódców, jak i - w późniejszych epokach historii narodu - wobec królów i proroków. Generalnie można ich zdefiniować jako klanowych lub plemiennych przywódców, pełniących ważną funkcję w życiu społecznym i religijnym ${ }^{4}$. Byli oni namaszczeni przez Boga na Jego posłanników, przeznaczeni do przekazania określonego orędzia lub wykonania zadań. Starszyzna zaś reprezentowała zawsze wobec nich

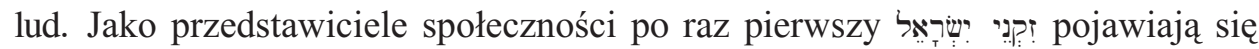
w Wj 3,18, stając się adresatami przesłania, z jakim ma się do nich zwrócić Mojżesz z Bożego nakazu:

Oni tych stów ustuchajq.

I pójdziesz razem ze starszymi z Izraela do króla egipskiego i powiecie mu:

Pan, Bóg Hebrajczyków, nam się objawit.

Pozwól nam odbyć drogę trzech dni przez pustynię,

abyśmy złożyli ofiary Panu, Bogu naszemu.

Werset funkcjonuje wpierw w pasażu w. 16-22, w którym s t a r s i dwukrotnie stają się adresatami przesłania, z jakim Mojżesz zwraca się do nich (w. 16.18).

\footnotetext{
${ }^{3}$ Nie rozpatrujemy także problemu historyczności omawianych tekstów, czyli zwłaszcza odpowiedzi na pytanie, czy starszyzna jako osobna grupa społeczna w ogóle istniała już w czasach niewo-

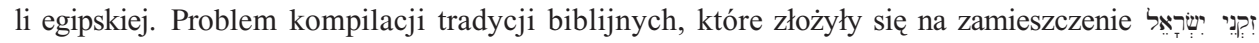
w tekstach ksiag natchnionych, czytelnik może zgłębić w opracowaniu H. Cazellesa, Autour de l'Exode, Paris 1987, s. 250-251.

${ }^{4}$ Tę uwagę należy dodać do wzmianki historycznej, podanej przez J. Lemańskiego, Księga Wyjścia, w: Nowy Komentarz Biblijny, t. 2: Stary Testament, Częstochowa 2009, s. 152. Autor definiuje ich jedynie socjologicznie, co zawęża zdecydowanie biblijne pojmowanie ich roli w społeczności izraelskiej czasów niewoli i wyjścia. Taka definicja jest jednak całkowicie do przyjęcia w rozważaniach historycznych.
} 
Obecnie Bóg zapowiada od razu swemu słudze, że staną się posłuszni jego słowom ${ }^{5}$. To zapewnienie ma wzbudzić w Mojżeszu pewność, że Bóg nie opuści go w momencie spotkania, oraz odwagę do wykonania całego trudnego przedsięwzięcia. Oznacza to również, że stars zy zn a będzie otwarta na to, co przekaże jej Mojżesz, i uwierzy głoszonej przez niego prawdzie. W co mieli uwierzyć stars i ludu? Otóż wpierw w objawienie się Boga Mojżeszowi (w. 16b), ujawnienie świadomości Boga co do losu Jego ludu w niewoli egipskiej (w. 16b) oraz decyzję o wyprowadzeniu ludu z Egiptu i zaprowadzeniu go do Ziemi Obiecanej (w. 17). Tak szokujące wiadomości w czasie, gdy lud od kilku już wieków doznawał największych upokorzeń i traktowany był w bezwzględny sposób, mogły wzbudzić albo całkowitą niewiarę, albo przeciwnie wiarę wynikająca $\mathrm{z}$ tego, że nikt przy zdrowych zmysłach nie mógłby zakomunikować takich nowin, jeśli nie miałby poparcia ze strony Boga Izraela. W żadnym wypadku bowiem jednostka nie rzuciłaby wyzwania całemu aparatowi ucisku państwa i jego monarsze, gdyby nie pewność, że siła wyższa zadziała w tym właśnie kierunku, poskramiając potęgę władcy najsilniejszego państwa w regionie. Mojżesz zatem mógł liczyć się z odrzuceniem jego przesłania. Czyżby jednak nie wierzył $\mathrm{w}$ Boże zapewnienie? Wydaje się, że nie o to chodziło autorowi natchnionemu, gdy zanotował tę wątpliwość w ustach sługi Bożego (Wj 4,1). Mojżesz nie tyle wątpił w prawdziwość Bożej zapowiedzi, ile od początku miał nadzieję, że uda mu się uniknąć misji, którą natychmiast odczuł jako zbyt ciężką jak na jego ludzkie możliwości. Tę tezę potwierdza późniejsza część jego rozmowy z Bogiem $(4,10.13)$. Wobec tego od razu zaczął wymieniać ewentualne trudności, nie zważając na słowo Pana, który raz zapewniwszy o swym działaniu, nigdy się ze swego słowa nie wycofuje ${ }^{6}$. Tę samą rangę mają zapowiedzi Boga dotyczące bliższej lub dalszej przyszłości.

Następnie Bóg nakazał mu zebrać stars zy ch I zraela, z którymi miał udać się do faraona, by w Jego imieniu przedstawić mu żądania. Nasuwa się więc pytanie, jaką rolę mieli odegrać owi s t a r s i, którzy przez cały czas dialogu między obiema głównymi postaciami nie rzekli ani jednego słowa i stali się niemymi jego uczestnikami? Można na nie udzielić dwóch odpowiedzi. Po pierwsze, widać wyraźne wyróżnienie starszyzny, która pełniąc obowiązki lidera społeczności, stała się wobec króla egipskiego reprezentantem pokrzywdzonego i zniewolonego ludu ${ }^{7}$. Wyróżnienie to z kolei może mieć dwojakie podstawy: są to stali

\footnotetext{
${ }^{5}$ Stwierdzenie to dotyczy postawy całkowicie przeciwnej temu, co w swej późniejszej historii naród prezentował wobec Boga, którego czyny kwestionował zwłaszcza poprzez odmawianie wiary Jego prorokom, por. B.S. Childs, The Book of Exodus. A Critical, Theological Commentary, The Old Testament Library, Louisville 1976, s. 77.

${ }^{6}$ Por. G. Vanhoomissen, En commençant par Moüse. De l'Égypte à la Terre promise, coll. Écritures, Lumen Vitae vol. 7, Bruxelles 2002, s. 120.

${ }^{7}$ Por. D.K. Stuart, Exodus. An Exegetical and Theological Exposition of Holy Scripture, w: New International Version - New American Commentary, vol. 2, red. E.R. Clendenen, Nashville 2006, s. 124-125.
} 
przedstawiciele ludu, wybrani przezeń do wypełnienia określonych zadań, zwłaszcza porząadkowania życia wewnątrz społeczności i tym samym nadawania jej właściwego kierunku rozwoju. Funkcje te mogli pełnić z racji swego podeszłego wieku i zdobycia dużego życiowego doświadczenia ${ }^{8}$. Drugą zaś podstawą udziału w rozmowie Mojżesza z faraonem była konieczność oznajmienia ludowi jej wyników. W obu wypadkach istotny był autorytet zarówno osobisty, jak i wynikający z piastowanych przez nich funkcji. Można też przypuszczać, że Bogu zależało na tym, by Jego sługa nie stawał samotnie wobec potęgi króla egipskiego, lecz został wsparty obecnością przedstawicieli ludu, która świadczyła o tym, że jest jego reprezentantem ${ }^{9}$. Dzięki temu faraon wiedział, że misja Mojżesza nie jest wybrykiem rozkapryszonego dziwaka, lecz znakiem nadziei całego zniewolonego ludu, którego przedstawiciele przybyli wespół z nim.

Kolejnym godnym uwagi tekstem jest też $\mathrm{Wj} 12,21^{10}$ :

Mojżesz zwołat wszystkich starszych Izraela i rzekt do nich:

Odtaczcie i weźcie baranka dla waszych rodzin i zabijcie jako paschę.

Akcja opowiadania toczy się w krucjalnej dla narodu chwili opuszczenia Egiptu, już bezpośrednio przed złamaniem uporu faraona przez Boga za pomocą ostatniej plagi - zabicia pierworodnych Egiptu (12,29-31). Zanim jednak Bóg tego dokonał, zadaniem Mojżesza było przygotowanie całego ludu do spożycia pierwszego w historii narodu posiłku paschalnego ${ }^{11}$. Jednak wspomnienie s t a r s z y ch w tym tekście jawi się jako wyraźna niekonsekwencja pisarska. W takim bowiem brzmieniu pascha dotyczyłaby jedynie właśnie starszyzny, nie zaś całego narodu, na co z kolei wskazuje dalsza część relacji autorskiej (w. 22-27), zwłaszcza zaś w. 27, mówiący już o całym ludzie, który ukląkł i oddał pokłon Panu. Także plaga śmierci ominąć miała wszystkie domy izraelskie, nie tylko mieszkania starszych (w. 23). Wreszcie późniejsze rytualne zapytanie dzieci o znaczenie całego obrzędu musi być rozumiane jako pytanie powszechne, tzn. zadawane przez wszystkich przedstawicieli następnych pokoleń, nie tylko tych, które rodziły się w domach starszyzny (w. 26). W 12,3-4 widnieje także zapis

${ }^{8}$ Por. m.in. Rdz 25,8; 35,29; Kpł 19,32; Lb 22,7; Pwt 21,19-21; 22,15-18; 25,8-9; 32,7; Iz 9,14; Jr 26,17; Lm 4,16; 5,12; Ez 7,26. W większości jednak tekstów autorzy biblijni niczego konkretnego nie sugerują co do wieku członków tej warstwy społecznej, por. generalne obserwacje J.L. McKenzie, The Elders in the Old Testament, „Biblica” 48 (1959), s. 522-540.

${ }_{9}^{9}$ Właśnie dlatego musiał Mojżesz wpierw ich przekonać o prawdziwości swej misji, wykonując cudowne znaki zapowiedziane przez Boga w 4,29-30, por. także W.H.C. Propp, Exodus 1-18. A New Translation with Introduction and Commentary, The Anchor Bible, vol. 2, New York - London - Toronto - Sydney - Auckland 1998, s. 206.

${ }^{10}$ Tę samą teologię zawiera także tekst Kpł 9,1, dlatego nie omawiamy go w sposób odrębny.

${ }^{11}$ Jako jeden z najstarszych tekstów tradycji paschalnej, por. G. Vanhoomissen, En commençant par Moïse, dz. cyt., s. 141. 
o baranku dla każdego domu izraelskiego. Ostatecznie to cały naród miał opuścić niewolę, nie tylko starsi, stąd pascha z definicji musi dotyczyć wszystkich członków ludu. Powyższe argumenty sugerują jednoznacznie, że st a rsi I z ra el a zostają zanotowani w rzeczonym wersecie albo jako glosa, albo jako przedstawiciele wszystkich rodzin izraelskich. Najprawdopodobniej pojawiają się oni znów jako reprezentanci ludu, jako pierwsi pośród równych, którzy mieli niejako rozpocząć obrzęd składania ofiary baranka paschalnego, a za ich przykładem mieli pójść wszyscy pozostali Izraelici. Autor biblijny wyraźnie chciał wyeksponować ich przewodnią rolę wobec pozostałej rzeszy Izraela, w tym konkretnym kontekście dotyczy to funkcji rytualnych, które mają wykonywać jako pierwsi spośród społeczności, by następnie przesłać orędzie wszystkim członkom wspólnoty ${ }^{12}$. Ponadto ukazane zostaje ich bezdyskusyjne posłuszeństwo nakazom Mojżesza, być może w odróżnieniu od późniejszego oporu ludu w drodze do Ziemi Obiecanej. Jest bowiem rzeczą znamienną że הָ nie stają nigdy po stronie ludu wówczas, gdy wybucha jakikolwiek spór między Mojżeszem a Izraelitami ${ }^{13}$. Narratorzy sugerują tym samym, że opowiadali się oni zawsze po stronie wodza ludu w jego konfliktach ze zniecierpliwionym ludem, o czym przyjdzie jeszcze kilka słów napisać. Dlatego niektórzy egzegeci trafnie wskazują, że określenie s t a r s i ludu nie dotyczy wieku, lecz urzędu już to głowy rodziny, już to ważniejszych przedstawicieli poszczególnych plemion ${ }^{14}$.

Kolejnym przykładem tekstu zawierającego omawiany zwrot jest Joz 7,6:

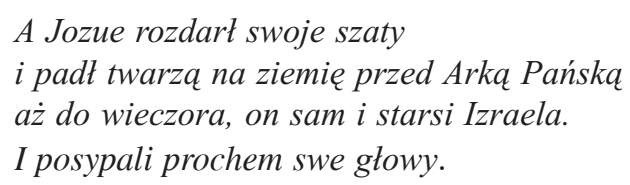

Tekst należy do szerszego passusu (w. 1-15) omawiającego sprawę przywłaszczenia sobie zdobyczy wojennej przez niektórych żołnierzy izraelskich (w. 1), chociaż wszelkie dobra zgodnie z Bożym nakazem powinny zostać zniszczone jako obłożone klątwą (Pwt 7,2; 20,17; Joz 6,18). Skutkiem tego nieposłuszeństwa była przegrana Izraelitów w wypadzie na miasto Aj, którego obrońców zlekceważono (w. 2-5). Wymowna jest tu niewielka liczba obrońców miasta, którzy dali radę wiele liczniejszym wojownikom z armii Jozuego, co udowadnia, że nie

${ }^{12}$ Por. J. Lemański, Księga Wyjścia, dz. cyt., s. 294.

${ }^{13}$ Nawet w 5,19-21, gdy przywódcy ludu atakują Mojżesza i Aarona za rozpaczliwe położenie Izraelitów po nieudanej, pierwszej ich interwencji u faraona, nie ma wśród nich st a r s z y c h. Stąd nadużyciem jest przypisywanie im sprzeciwu wobec późniejszego wodza ludu, jak to zbyt szybko czyni D.K. Stuart, Exodus, dz. cyt., s. 287-288.

${ }^{14} \mathrm{~W}$ ten sposób J. Gill, por. http://www.studylight.org/com/geb/view.cgi?book=ex\&chapter $=012 \&$ verse $=021$ [dostęp 22.08.2012]. 
liczba żołnierzy, lecz postawa Boga decyduje o zwycięstwie nawet wówczas, gdy koleje bitwy obracają się przeciw Jego ludowi. Jedyną z możliwych reakcji Jozuego jako przywódcy ludu, a zarazem wiernego czciciela Boga było rytualne rozdarcie szat, padnięcie na twarz w błagalnym geście i posypanie głowy popiołem na znak żałoby po zabitych. To samo uczynili również starsi Izraela, tu wyraźnie na znak solidarności ze swym wodzem.

Trudno określić precyzyjnie, jakie znaczenie ma ich gest, lecz wiele wskazuje, że nie chodzi jedynie o solidarność z Jozuem. Motyw ich działania ma charakter ściśle teologiczny. Czyniąc to, co Jozue, jawią się przede wszystkim jako reprezentanci ludu wobec Boga, co oznacza, że w imieniu tegoż ludu pragną wpierw przebłagać Boga, ponieważ przegraną w bitwie uznali za ewidentny przejaw braku Jego łaski i pomocy w walce. Zinterpretowali to w jedyny możliwy sposób: nastąpiło przekroczenie prawa Bożego. Pewna trudność interpretacyjna może wiązać się z w. 7; czytając go, można odnieść wrażenie, że Jozue nie zna przyczyny klęski swych wojsk i w związku z tym stawia Bogu zasadnicze pytanie o sens przechodzenia przez Jordan i zdobywania Ziemi Obiecanej, skoro teraz Izraelici przegrywają ${ }^{15}$. Jednak już w w. 8 pojawia się błaganie do Boga o przebaczenie, co świadczy o świadomości Jozuego, że musiał nastapić grzech niewierności Bożym zaleceniom. Wówczas w. 7 należałoby odczytywać raczej jako pytanie, czy obecna przegrana jest jedynie epizodem i nie wpłynie decydująco na całość Bożego projektu względem Izraela, czy też występek był tak poważny, że Bóg zdecydował się zakończyć współpracę ze swym ludem i nie oddawać kraju w jego ręce? Z pewnością te same problemy mieli także starsi I z ra e la, gdy towarzyszyli Jozuemu podejmującemu próby przebłagania Boga. Rozdarcie szat powodowane jest z pewnością żalem po śmierci 36 zabitych żołnierzy, ale też niepewnością co do Bożej postawy wobec ludu ${ }^{16}$. S t a r s i jednak towarzyszą Jozuemu przede wszystkim po to, by reprezentować cały lud wobec Boga w konkretnej sytuacji grzechu. Dzięki nim Jozue nie działał w osamotnieniu, lecz spotkał się z aprobatą przedstawicieli całego ludu, który w ten sposób odcinał się od winowajców. Zdaniem niektórych badaczy, grupą s t a r s z y ch towarzyszących Jozuemu mogło być owych siedemdziesięciu (Lb 11,16), stanowiących zapewne radę przyboczną wodza ludu, zatem poczuwających się tym bardziej do towarzyszenia mu $\mathrm{w}$ jego żałobie i przebłaganiu ${ }^{17}$.

Następnym tekstem godnym rozpatrzenia jest 8,10 tej samej księgi:

\footnotetext{
${ }^{15} \mathrm{~W}$ w. 5b widnieje wzmianka, że serce ludu rozlało się jak woda, tzn. całkowicie wyczerpała się jego odwaga. W takim razie każda następna bitwa przynosiłaby same klęski. Wycofanie się Boga z pomocy udzielanej ludowi byłoby dopełnieniem katastrofy u bram Ziemi Obiecanej.

${ }^{16}$ Por. http://www.studylight.org/com/guz/view.cgi?book=jos\&chapter=007 [dostęp 23.08.2012].

${ }^{17}$ Por. http://www.studylight.org/com/geb/view.cgi?book=jos\&chapter=007\&verse=006 [dostęp 23.08.2012].
} 
Wstawszy wcześnie rano, dokonat przegladu ludu

i wraz ze starszymi Izraela na czele poprowadzit lud przeciw Aj.

Kontekst w. 3-13 wspomina o bitwie o Aj, przed którą Jozue udzielił szczegółowych instrukcji co do organizacji i przebiegu batalii, której czołowym elementem była zasadzka (w. 9-13). Po udaniu się w góry grupy mającej zająć miasto (w. 9) Jozue postanowił poprowadzić resztę ludu przeciw obrońcom z zamiarem zaatakowania ich. Służyć miał temu manewr rozmieszczenia wojsk pod miastem, a ta manifestacja rzekomych zamiarów de facto miała zmylić przeciwników (w. 11-13). W tej sytuacji w. 10 relacjonujący przegląd ludu ukazuje, że głównym celem było najprawdopodobniej przeprowadzenie inspekcji połączone z wydaniem ostatnich rozkazów porządkowych i przekazanie informacji co do sposobu ataku na miasto. W ten sposób Jozue zyskał pewność co do możliwości ataku, markowania ucieczki, porządku wycofywania się itd. Na takie chyba właśnie rozumienie sensu najbardziej wskazuje sytuacyjny kontekst tekstu, jakkolwiek niektórzy egzegeci dopatrują się próby przeliczenia ludu przez Jozuego ${ }^{18}$ lub słownego zachęcenia do walki ${ }^{19}$.

Jaką rolę odegrali w tym przypadku s t a r s i ? Tekst źródłowy brzmi tu dosłownie: „i wyszedł on i starsi Izraela naprzeciw ludu Aj”. Brzmienie całego wersetu nie pozwala mieć wątpliwości, że Jozue i starszyzna ludu nie działali w osamotnieniu, lecz wespół z całą resztą narodu. Oznacza to, że wódz i towarzysząca mu starszyzna szli na czele armii izraelskiej w stronę obwarowanego miasta. Rolą zatem starszych było prowadzenie ludu pod rozkazami Jozuego. Z uwagi na bezdyskusyjne posłuszeństwo dodawali odwagi tym, którzy jeszcze nie tak dawno stracili ją na skutek wcześniejszej nieudanej próby zdobycia miasta. Kontekst uwidacznia zatem jednoczący autorytet starszyzny, zwłaszcza w ważnych i trudnych sytuacjach, które cały lud musiał przechodzić, by osiagnąć zamierzony cel, czyli zdobyć i zasiedlić Ziemię Obiecaną. Z racji wspomnianych wydarzeń nie można w זִ̣ widzieć ludzi w wieku podeszłym, lecz przyboczną gwardię wodza naczelnego lub rodzaj konsylium wspierającego go w boju. Jednak z tego jednego kontekstu nie można wnosić, że starsi I zrae la pełnili jaką́s ważną funkcję militarną ${ }^{20}$. Wcześniejszy tekst sugeruje właśnie coś odwrot-

\footnotetext{
${ }^{18}$ Por. http://www.studylight.org/com/tsk/view.cgi?book=jos\&chapter=008 [dostęp 23.08.2012].

${ }^{19}$ Por. D.M. Howard, Jr., Joshua. An Exegetical and Theological Exposition of Holy Scripture, w: New International Version - New American Commentary, vol. 5, red. E.R. Clendenen, Nashville 1998, s. 203.

${ }^{20}$ Niektórzy komentatorzy sugerują, że mogli to być oficerowie niższej rangi, dowodzący poszczególnymi jednostkami wojskowymi, por. http://www.studylight.org/com/geb/view.cgi?book=jos $\&$ chapter $=008 \&$ verse $=010$ [dostęp 23.08.2012]. Duchową interpretację proponują inni, widzący w działaniach starszych zapowiedź wierności wymaganej przez Chrystusa wobec Jego uczniów, por. http://www.studylight.org/com/guz/view.cgi?book=jos\&chapter=008 [dostęp 23.08.2012].
} 
nego: starszyzna nie udała się na pierwszą potyczkę pod Aj, zatem jej udział w walce nie był obowiązkowy i jednoznacznie konieczny.

\section{2. Świadczący o potędze Boga}

Wj 17,5.6 zawiera pierwszy z prezentowanych opisów cudu, jakiego dokonał Mojżesz na rozkaz Boży, czego świadkiem była stars zy zna I zraela:

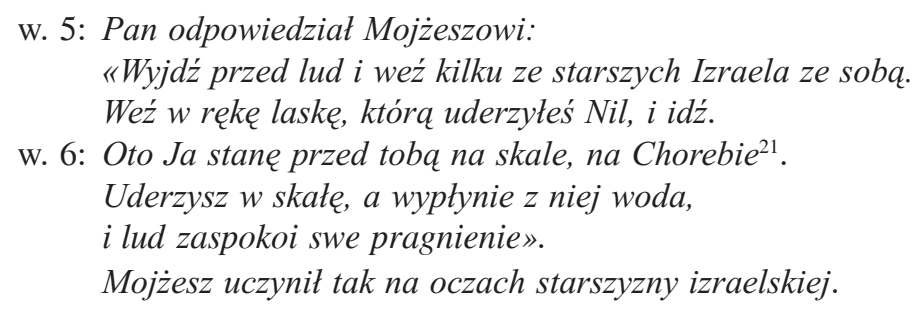

Opisywana w wersetach akcja toczy się w kontekście jednej z pierwszych kłótni między Mojżeszem a ludem na pustyni Sin (w. 1-7). Wywołał ją brak wody do picia i możliwości napojenia licznych stad, które opuściły Egipt (w. 1-3). W tej sytuacji wybraniec Boży mógł jedynie rozpaczliwie wołać do Pana, by zechciał przyjść z pomocą. Argumentem zachęcającym Boga do działania ma być możliwość ukamienowania Mojżesza przez rozwścieczony tłum, przez co załamałaby się koncepcja wędrówki ku Ziemi Obiecanej (w. 4). Od razu widać, że Bóg tę argumentację przyjmuje i bez dalszych dialogów nakazuje spełnienie kilku czynności, które umożliwią napojenie ludu i bydła. Ma się zatem dokonać coś niezwykłego, co zostanie zinterpretowane przez cały lud jako ewidentny cud. Tekst nie precyzuje, czy cała społeczność stanie się świadkiem dokonujących się wydarzeń, czy tylko wybrana grupa ludzi. Pewne jest, że lud odczyta to jako cud, skoro woda nagle się pojawi w miejscu, które do tej pory było jej zupełnie pozbawione. Na wstępie można już tymczasem stwierdzić, że właśnie ów brak naocznego świadectwa ze strony całości ludu tym bardziej usprawiedliwia obecność starszyzny przy Mojżeszu.

Werset 5 układa następującą sekwencję faktów: wyjście przed lud - towarzyszenie starszych - zabranie cudownej laski egipskiej - pójście przed siebie. Pierwszy z elementów sekwencji wskazuje, że z nakazu Bożego w każdej, nawet najtrudniejszej sytuacji Mojżesz ma nadal przewodzić ludowi, także wówczas, gdy ten się buntuje. Nie ma prawa wycofywać się ze strachu lub pod wpływem

\footnotetext{
${ }^{21}$ Posługujemy się tą właśnie pisownią ze względu na hebrajską literę $\pi$, rozpoczynającą termin oryginalny, a transkrybowaną na „,ch”. Bardziej rozpowszechniona jest, niestety, błędna w języku polskim pisownia „Horeb” zaczerpnięta z przekładów angielskich.
} 
zniechęcenia ${ }^{22}$. Jest to przecież dopiero początek drogi ku wyzwoleniu i początek ciągle - jak się później okaże - narastających trudności. W takiej sytuacji stars i I zrae la niewątpliwie odgrywają rolę zarówno tych, którzy - jako reprezentanci ludu - później będą przed nim świadczyć o sposobie realizacji cudu, jak i wspierających wodza w próbach utrzymania ludu w posłuszeństwie Bogu. Ta dwojaka rola wydaje się tu najważniejszą podstawą ich znaczenia w całej społeczności przez cały okres wędrówki. Okazuje się bowiem, że ich podstawowym zadaniem nie jest wyrażanie interesów ludu, lecz właśnie świadczenie o wielkości i dobroci Boga wobec niego. Tym samym mają zawsze stać po stronie Mojżesza - tego, który reprezentuje Boga wobec Izraela ${ }^{23}$.

Podobną myśl przekazuje w. 6, opisujący sposób wykonania cudu przez Mojżesza $\mathrm{w}$ towarzyszącej mu teofanicznej obecności Boga, jednakże z ważnym dodatkiem, że uczynił to w obecności stars zy zny ludu. Właśnie starsi mieli być pierwszymi świadkami, by później móc przekazać wiadomość o tym osobom, które z różnych racji nie uczestniczyły we wspomnianym zdarzeniu ${ }^{24}$. Do nich zatem należało zarówno stwierdzenie prawdziwości samego zdarzenia, jak i jego właściwa interpretacja jako cudu Bożego ${ }^{25}$. Ponadto - i to wcale nie mniej ważne - do stars z y ch należeć będzie wyciagnięcie praktycznych konsekwencji z dokonanego cudu. Pierwszą z nich jest nawoływanie do posłuszeństwa Bogu i Jego przedstawicielowi i niewywoływanie buntów w różnych trudnych sytuacjach, które najczęściej mają się stać sposobnością do okazania Bogu zaufania.

\section{Lb 16,25}

Wtedy podnióst się Mojżesz i udat się do Datana i Abirama,

a starsi Izraela poszli za nim.

Sam przywołany werset nie objaśnia sytuacji, w kontekście której się znajduje, a jest to sytuacja nadzwyczaj niebezpieczna dla samego Mojżesza oraz całego zgromadzenia. Wywołana została rebelią Koracha, Datana i Abirama oraz

${ }^{22}$ Inne możliwe thumaczenie to: „wyjdź naprzeciw ludu” w sensie: „wyjdź do konfrontacji z nim”, by ukazać wpierw potęgę Boga i opartą na niej własną siłę i w ten sposób odeprzeć siłę buntu, por. W.H.C. Propp, Exodus 1-18, dz. cyt., s. 605.

${ }^{23}$ Odpowiednik Wj 17,1-7 w Lb 20,1-13 nie zawiera już wzmianki o starszych Izraela, co uzasadnia stwierdzenie, że tekst Lb jest późniejszy, wobec czego akcentuje Aarona ich kosztem, por. J.L. Ska, Introduction à la lecture du Pentateuque. Clés pour l'interpretation des cinq premiers livres de la Bible, Bruxelles 2000, s. 89.

${ }^{24}$ Por. J. Lemański, Księga Wyjścia, dz. cyt., s. 370; W.H.C. Propp, Exodus 1-18, dz. cyt., s. 606; $\mathrm{http} / / / \mathrm{www}$. studylight.org/com/geb/view. cgi?book=ex\&chapter=017\&verse=005 [dostęp 23.08.2012].

${ }^{25}$ A tym samym stałej Jego obecności pośród ludu oraz zwrócenia myśli we właściwym kierunku, ku jego faktycznemu Twórcy, por.

http://www.studylight.org/com/mhc-com/view.cgi? book=ex\&chapter=017 [dostęp 23.08.2012]. 
250 innych osób (16,2). Można sobie tylko wyobrazić konsekwencje owego buntu dla społeczności, gdyby udało im się przekonać lud do nieposłuszeństwa względem Mojżesza. Ludzie ci doprowadzili bowiem do załamania się pozycji Mojżesza jako wodza społeczności, uzurpując sobie prawo współdecydowania o losach powracających z niewoli (w. 3-4). Jedynym wyjściem z tej sytuacji było bezpośrednie odwołanie się do samego Boga, który miał rozstrzygnąć o słuszności postawy Mojżesza lub zakwestionowaniu jej przez przyznanie racji buntownikom (w. 5-19). Bóg zdecydował zaś, po czyjej stronie stoi, dekretując całkowitą i bezwzględną zgubę rebeliantów (w. 20-21.26-33). Szczególne znaczenie ma suplikacyjna modlitwa Mojżesza, pragnącego uratować resztę ludu, ponieważ wskazuje ona na jego wielkoduszność nawet wobec, jeśli nie winowajców, to z pewnością biernych obserwatorów zajścia, którzy nie chcieli poprzeć wodza ludu (w. 22-24).

W takim kontekście główny w. 25 opisuje wyjście Mojżesza wraz ze starszyzną ludu do winowajców w celu obwieszczenia wyroku, jaki wydał na nich Bóg. Warto zauważyć, że wyrok ów został zapowiedziany nie samym buntownikom, lecz pozostałej części ludu, która miała natychmiast oddzielić się od nich, by uniknąć losu, jaki zostanie im za moment zgotowany (w. 26). Warto wspomnieć, że zapowiedź natychmiast wykonano (w. 27a). Autor biblijny nie omieszkał w końcu przedstawić buntowników jako ludzi o zatwardziałym sercu, hardych, bezczelnych i pewnych swej racji, ponieważ $\mathrm{w}$ otoczeniu swych najbliższych ośmielili się sprzeciwić Mojżeszowi (w. 27b).

Także w tym tekście stars i I z ra e la okazali się tą częścią społeczności, która murem stanęła za swoim przywódcą, dzieląc jego odpowiedzialność za losy całego zgromadzenia. Zaświadczyli zatem, że nie cała społeczność przyłącza się do buntu. Wręcz przeciwnie, to winowajcy pozostaną osamotnieni i skazani na zagładę. Wielkość Bożego działania, opisanego w w. 31-33, sprawiła, że stali się naocznymi świadkami potęgi Boga, przekonali się bowiem o ogromie, nagłości i bezwzględności kary, jaka spadła na rebeliantów z Bożego dopustu. Relacjonując ją później tym członkom zgromadzenia, którzy nie byli bezpośrednimi jej świadkami, stawali się wiarygodnymi reprezentantami prawdziwości powołania Mojżesza wobec ludu ${ }^{26}$. Pewien problem $\mathrm{z}$ ustaleniem ich tożsamości wynika jedynie z w. 2 wymieniającego „książąt społeczności, przedstawicieli ludu” oraz „ludzi szanowanych”. W żadnej z tych grup s tars i nie mogli się pojawić, nie biorąc udziału w rewolcie. Nie może zatem chodzić o ludzi starszych wiekiem, lecz zapewne wąską grupę owych siedemdziesięciu, których wcześniej Mojżesz wybrał na swych pomocników, zwłaszcza do osądzania licznych sytuacji życio-

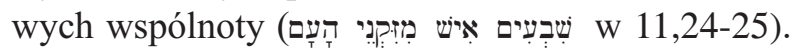

${ }^{26}$ Niekiedy nazywani są zatem autorytetem świeckim, paralelnie do religijnego autorytetu Mojżesza, por. H. Cazelles, A la recherche de Moïse, Paris 1979, s. 134. 


\section{Udział w specjalnych wydarzeniach}

Opisywane w tym właśnie punkcie wydarzenie może stanowić dobry wstęp do złożenia odpowiedniego świadectwa, jednak w poniższych tekstach nie ono wysuwa się na pierwsze miejsce, lecz samo wydarzenie, w którym biorą udział stars i I zraela. Pierwszą relacją o takim zdarzeniu jest $\mathrm{Wj} 18,12$ :

Jetro, teść Mojżesza, złożyt Bogu calopalenia i ofiary.

Aaron $i$ wszyscy starsi z Izraela przyszli,

Aby spożyć chleb z teściem Mojżesza przed Bogiem.

Werset funkcjonuje w relacji o spotkaniu kapłana Jetry, teścia Mojżesza, z nim samym na pustyni. Jetro przywiódł ze sobą Seforę, żonę Mojżesza, i jego dwóch synów, których ten wcześniej odesłał do domu rodzinnego w Madianie (w. 2-6). Mojżesz, dowiedziawszy się o tym, wyszedł naprzeciw pielgrzymom, witając się z nimi i opowiadając o cudach zdziałanych przez Boga dla Jego ludu, co szczerze ucieszyło Jetrę, który chwalił Boga całym sercem (w. 7-11). Wdzięczność za dokonane cuda stała się powodem złożenia ofiar dziękczynnych Bogu przez kapłana madianickiego (w. 12a). Z tychże ofiar z kolei przygotowano posiłek, do którego dołączyli także: Aaron, brat Mojżesza, oraz st a r s i I zra el a. Ich początkowa nieobecność nie dziwi. Wszakże teść pragnął spotkać się przede wszystkim ze swym zięciem. Ciekawy jest tu jednak zwrot o „uczcie przed Bogiem”, co sugeruje położenie namiotu Mojżesza prawdopodobnie w pobliżu słupa ognistego, w którym przebywał Bóg (Wj 13,21-22), ponieważ Mojżesz permanentnie z Nim rozmawiał. Wobec tego uczta ofiarna $\mathrm{z}$ udziałem kapłana Madianitów i pozostałych uczestników odbywała się w tym właśnie miejscu, blisko Boga, przed Jego obliczem. Jeśli zaś zbudowany został już przybytek, wówczas uczta dokonywałaby się wprost przed nim jako miejscem zamieszkania Boga pośród Izraela ${ }^{27}$. Jest to jednak tylko sugestia, ponieważ dotąd nie było o tym żadnej wzmianki. Natomiast pasaż 17,15-16 relacjonuje budowę ołtarza. Sugeruje to, że teść Mojżesza mógł złożyć ofiary właśnie na nim² ${ }^{28}$. Dlatego niektórzy sądzą że chodzi jedynie o ucztę ze świadomością obecności Boga przebywającego pośród swego ludu, z sercem prawym, czystym, co pozwala wszystko czynić w bliskości Boga ${ }^{29}$. Z kolei spożywanym chlebem bez wątpienia była manna, którą żywił się naród z łaski swego Wyzwoliciela. Jaki jest więc sens przybycia Aarona i starszyzny? Prawdopodobnie autor biblijny chciał zaznaczyć,

${ }^{27}$ Zwrot לפבְני הָאלדהים, 'przed Bogiem', znany jest jeszcze w Pwt 12,5-7; Joz 24,1; Sdz 21,2; 1 Krn 13,8; 16,1.6; 29,21-22, i odnosi się zawsze do przybytku jako domu Bożego lub do Arki Przymierza.

${ }^{28}$ Por. D.K. Stuart, Exodus, dz. cyt., s. 413.

${ }^{29}$ Por. http://www.studylight.org/com/geb/view.cgi?book=ex\&chapter=018\&verse=012 [dostęp 24.08.2012]. 
że uczta miała jednak charakter sakralny, nie czysto świecki, jakkolwiek nie z powodu obecności Aarona, który występuje tutaj jako przywódca ludu, a nie kapłan. Sakralny wymiar nadała jej obecność teścia Mojżesza, który był kapłanem, a uczestnictwo Aarona zostaje usprawiedliwione przyszłym ordynowaniem go na pierwszego w historii kapłana Izraela. Z kolei st ars z y zn a została dopuszczona do uczty prawdopodobnie w celu wyróżnienia jej spośród całej wspólnoty, reprezentowania jej oraz stwierdzenia łączności między nią a wodzem ludu, a tym samym nadania jej pewnego autorytetu ${ }^{30}$. W ten sposób również w sensie teologicznym starsi stają się znakiem jedności świeckiej części społeczności z przyszłą religijną wobec Boga z jednej i pozostałego świata z drugiej strony ${ }^{31}$. Możliwa jest jednak także interpretacja tej uczty jako antycypacji uczty w bezpośredniej bliskości Boga, nieporównanie ważniejszej, ukazanej w Wj 24,9-11,

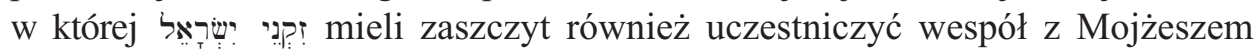
i Aaronem na świętej górze Choreb. Wówczas potwierdzony zostałby autorytet stars zy zn y wobec całej wspólnoty przez samego Boga.

Kolejne ważne wydarzenie z udziałem stars z y z y zostało zanotowane w Wj 24,1.9. Wszystkie one odnoszą się do zawarcia przymierza między Bogiem a Jego ludem za pośrednictwem wybranych przezeń przedstawicieli. W ten sposób starsi Izraela biorą udział w najważniejszym akcie prawnym łączącym nierozerwalnie naród wybrany i Jego Boga:

w. 1: I rzekt Pan do Mojżesza: «Wstap do Pana, ty, Aaron, Nadab, Abihu i siedemdziesięciu ze starszych Izraela i oddajcie pokton $z$ daleka.

w. 9: Wstapit Mojżesz wraz z Aaronem, Nadabem, Abihu i siedemdziesięciu starszymi Izraela.

Wersety te stanowią obramowanie pierwszej części relacji biblijnej o szczególnym zbliżeniu się do Boga wybranych przez Niego osób, do których należeli także s tars i (w. 1-9). Jednak perykopa poświęcona jest całkiem innej kwestii. Przedstawia sekwencję faktów ustanawiających przymierze między Bogiem a Jego ludem: obwieszczenie ludowi przez wodza wszystkich Bożych praw, zgodę ludu na posłuszeństwo wobec nich, zapisanie postanowień prawa w Księdze Przymierza, postawienie ołtarza, złożenie na nim ofiary przez młodzieńców Izraela, pokropienie ołtarza krwią ofiarna, publiczne odczytanie prawa z Księgi Przymierza, ponowną zgodę ludu na wypełnienie prawa, wreszcie pokropienie ludu

${ }^{30}$ Por. W.H.C. Propp, Exodus 1-18, dz. cyt., s. 631; J. Lemański, Księa Wyjścia, dz. cyt., s. 385 .

${ }^{31}$ Por. B.S. Childs, The Book of Exodus, dz. cyt., s. 335-336. 
krwią ofiarną (w. 3-8). Trudno precyzyjnie określić, dlaczego autor natchniony ujął ów akt zawarcia przymierza w ramy całkowicie innego wydarzenia ${ }^{32}$. Najprawdopodobniej jednak chciał przez to ukazać, że do Boga zbliżyć mogą się jedynie ci, którzy w pełni chcą respektować postanowienia przymierza, z drugiej zaś strony przymierze daje prawo do przebywania w bezpośredniej bliskości Boga. Wobec tego pierwszorzędną egzemplifikacją takiej postawy są wodzowie ludu oraz jego stars z y z n a, zawsze we wszystkim posłuszna ${ }^{33}$. Taka postawa teologicznie stawia ją między doskonałą niemal świętością i posłuszeństwem Mojżesza a grzesznością i oporem ludu ${ }^{34}$.

Teologiczna perspektywa obecnego wydarzenia wydaje się jednak znacznie szersza, co widać w świetle Wj 19,24 wyrażającego kategoryczny zakaz jakiegokolwiek zbliżania się innych, poza Mojżeszem, członków ludu do płonącej góry, by nie zostali ukarani śmiercią. Bóg podaje samemu tylko Mojżeszowi i towarzyszącemu mu Aaronowi wszystkie prawa, zaś lud ma się trzymać z daleka. Rozpatrywany w. 1 pod względem sytuacyjno-czasowym stanowi paradoksalną kontynuację 19,25 i 20,18-21, relacjonujących prawdopodobnie kilkakrotne wstępowanie Mojżesza na górę i schodzenie $\mathrm{z}$ niej w celu obwieszczenia ludowi wszystkiego, co otrzymał od Boga. Teraz jednak, już po nadaniu przepisów, obu mężom mają towarzyszyć jeszcze dwaj synowie Aarona oraz siedemdziesięciu stars z y ch. Wyraźnie widać ich rolę jako świadków nadania prawodawstwa, jakkolwiek tajemnicą ma pozostać dla nich sposób jego otrzymania. Warto także zwrócić uwagę, że liczba siedemdziesięciu podana została jedynie w tej szczególnej okazji. Nie chodzi zatem o jakiś trwały urząd, lecz jedynie o liczbę świadków konkretnego wydarzenia. Ponadto jednak stopniowo poszerza się krąg adresatów prawa, by ostatecznie objąć cały lud, który odnośne przepisy otrzyma za pośrednictwem swych wybrańców, w sposób widzialny potwierdzających swym autorytetem ich boskie pochodzenie ${ }^{35}$. Ów autorytet wynika nie $\mathrm{z}$ nich samych, ich mądrości lub prawości, ale wyłącznie $\mathrm{z}$ owego bezpośredniego spotkania $\mathrm{z}$ Bogiem ${ }^{36}$. W ich przypadku ma się ono odbyć w ściśle wyznaczony sposób składający się z dwóch etapów: oddania głębokiej czci i pokłonu Bogu z daleka oraz pozostania w tym oddaleniu w oczekiwaniu na Mojżesza, który - jako jedyny - otrzyma prawo przybliżenia się do Boga. Do głębi poruszeni tym, co prze-

\footnotetext{
${ }^{32}$ Pod względem literackim mamy do czynienia z dwoma osobnymi tradycjami: w. 1.9 należą do tradycji kapłańskiej, podczas gdy w. 3-8 mają wyraźne znamiona tradycji deuteronomistycznej, por. G. Vanhoomissen, En commençant par Moïse, dz. cyt., s. 155.

${ }^{33}$ Znów prawdopodobnie ci, którzy wcześniej zostali wyznaczeni do wspomagania Mojżesza za radą jego teścia w $\mathrm{Wj} 18$.

${ }^{34}$ Por. B.S. Childs, The Book of Exodus, dz. cyt., s. 504.

${ }^{35}$ Por. pr. zb. Association Catholique Française pour l'Étude de la Bible (ACFEB), Le Pentateuque. Débats et recherches, Lectio Divina, vol. 151, Paris 1992, s. 166-168.

${ }^{36}$ Chodzi zatem o ich legitymizację pośród ,narodu świętego”, por. J.L. Ska, Introduction à la lecture du Pentateuque, dz. cyt., s. 50.
} 
żyli, skutecznie wspomogą oni Mojżesza w promulgowaniu przepisów prawa, obwieszczając je pozostałym członkom zgromadzenia ${ }^{37}$.

Z kolei w. 9 pojawia się już po zaakceptowaniu przez cały lud prawa i deklaracji wierności mu, co pozwala Bogu przyznać kolejne przywileje reprezentantom zgromadzenia i dopuścić ich bliżej siebie, niż mogliby się spodziewać. W w. 10 podana jest wzmianka, że mogli oni w jakiś bliżej niesprecyzowany sposób oglądać Boga, jakkolwiek w świetle J 1,18 z pewnością nie bezpośrednio, i nie mieli wglądu w całość Bożej prawdy, lecz tylko w jej część. Widzieli także miejsce, gdzie Bóg stał, lecz nie potrafili wprost przyrównać oglądanej rzeczywistości do czegokolwiek na ziemi. Oglądali zatem coś w kształcie Jego stóp oraz ich podnóżek, który - ich zdaniem - przypominał drogocenne podłoże świecące w sposób nieporównywalny ze światłem ziemskim ${ }^{38}$. W myśl w. 11 Bóg pozwolił im oglądać cząstkę swej chwały oraz rzeczywistości nieba i dlatego nie zabił ich, co stałoby się, gdyby ktoś niepowołany zbliżył się do Niego. Z pewnością zostali bardzo umocnieni taką wizją otaczającego ich niebiańskiego świata ${ }^{39}$. Po doświadczeniu innego świata mieli możliwość spożycia posiłku, co z kolei wzmocniło ich siły fizyczne, a także udowodniło samą prawdziwość przeżyć mistycznych, ponieważ wiedzieli, że żyją oraz mogą jeść i pić. Mogli również nabrać pewności, że to, co przeżywali, działo się naprawdę i nie jest jedynie iluzją ${ }^{40}$. W ten sposób przekonująco mogli zaświadczyć przede wszystkim o boskim pochodzeniu prawa nadanego przez Mojżesza. Mieli już bowiem to samo doświadczenie bliskości Boga, jak sam wódz, chociaż oczywiście nie w takim jak on zakresie ${ }^{41}$.

Ważne informacje wnosi także tekst Lb 11,16-17.25.30:

w. 16: Rzekt Pan do Mojżesza:

«Zwołaj mi siedemdziesięciu mężów spośród starszych Izraela, o których wiesz, że sq starszymi ludu i nadzorcami, i przyprowadź ich do Namiotu Spotkania; niech tam stanq razem z tobq.

\footnotetext{
${ }^{37}$ Por. D.K. Stuart, Exodus, dz. cyt., s. 552-553.

${ }^{38}$ Por. http://www.studylight.org/com/geb/view.cgi?book=ex\&chapter=024\&verse $=010$ [dostęp 27.08.2012].

39 Por. http://www.studylight.org/com/mhc-com/view.cgi?book=ex\&chapter=024 [dostęp 27.08.2012].

${ }^{40}$ Widać tu wyraźne podobieństwo do zachowania się Jezusa po zmartwychwstaniu w relacji Łk 24,36-43.

${ }^{41}$ Tu znów widoczne jest podobieństwo tym razem do J 4,42 przedstawiającego reakcję mieszkańców samarytańskiego Sychar na bezpośrednie spotkanie z Jezusem, którzy stwierdzili, że niepotrzebne jest pośrednictwo kobiety, świadka spotkania przy studni.
} 
w. 17: Wtedy Ja zstapię $i$ będę z toba mówit; wezmę z ducha, który jest $w$ tobie, $i$ dam im, $i$ będa razem z tobq dźwigać ciężar ludu, a ty go sam już więcej nie będziesz musiat dźwigać.

w. 25: A Pan zstapił $w$ obłoku i mówił z nim.

Wzią z ducha, który byt $w$ nim,

i przekazat go owym siedemdziesięciu starszym.

A gdy spoczat na nich duch, wpadli w uniesienie prorockie.

Nie powtórzyło się to jednak.

w. 30: Po czym udat się Mojżesz

razem ze starszymi Izraela z powrotem do obozu.

Warto na początku podkreślić, że autor nie wspomina wszystkich זק̣ ludu, lecz jedynie siedemdziesięciu wybranych spośród nich. Mieli oni wspomóc Mojżesza w dźwiganiu ciężaru spraw ludu, którym sam nie mógł już podołać. Należy w tym miejscu omówić jednak nieco wspomniane zdarzenie, ponieważ

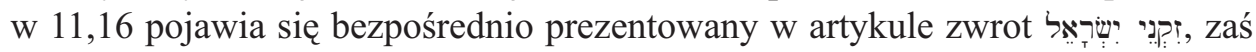
w w. 25 tego rozdziału rzeczownik הַזקנ z rodzajnikiem określonym, co jest wyraźnym odwołaniem właśnie do w. 16. Oba teksty należy zatem traktować łącz-

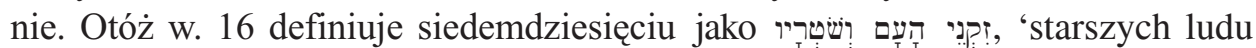

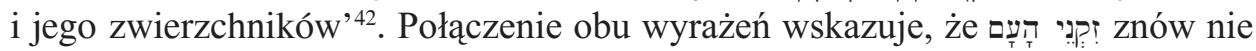
odnoszą się jedynie do starszych wiekiem, bo wiek nie odgrywa tu istotnej roli. Chodzi bardziej o pewną grupę społeczną, zajmującą wyróżnione miejsce w społeczności, obdarzoną pewną władzą i mogącą z tego tytułu reprezentować całość ludu ${ }^{43}$.

Wyjaśnienie sensu tego wydarzenia nie jest proste. Można być przecież pewnym, że Bóg, wyznaczając Mojżesza do przewodniczenia ludowi w drodze do Ziemi Obiecanej, zaopatrzył go wystarczająco we wszelkie potrzebne dobra i moce, by zadaniu temu mógł sprostać. Tezę tę paradoksalnie wzmacnia fakt, że w myśl w. 17 owych siedemdziesięciu starszych otrzymało właśnie z jego ducha, nie zaś bezpośrednio i wyłącznie od Boga ${ }^{44}$. Oznacza to, że Mojżesz owym duchem Bożym obdarzony został niezwykle hojnie, i to tak bardzo, że także im wystarczyło tegoż ducha, by mogli dźwigać z nim współodpowiedzialność za

${ }^{42} \mathrm{~W}$ ten sposób L. Koehler i in., Wielki stownik hebrajsko-polski i aramejsko-polski Starego Testamentu, red. wyd. pol. P. Dec, Prymasowska Seria Biblijna, Warszawa 2008, s. 440.

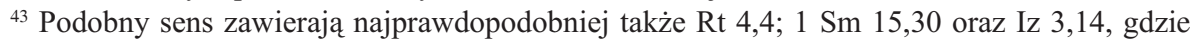

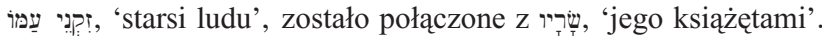

${ }^{44}$ Możliwość otrzymania ducha, posiadania go lub pozostawania pod jego wpływem ukazana została także m.in. w Lb 27,18; 1 Sm 10,6; 2 Krl 2,9.15; Ne 9,20; Iz 44,3; 59,20-21; Jl 2,28, a w Nowym Testamencie, por. np. J 7,39; Rz 8,9; 1 Kor 2,12; 12,4-11; 1 Tes 4,8; 1 P 1,22 oraz Jd 19. 
właściwy kierunek marszu ku wolności ${ }^{45}$. Taki kierunek egzegezy wyklucza też przypuszczenie, że Mojżesz mógłby utracić część tych niepowtarzalnych darów Bożych z powodu kilkakrotnego manifestowania słabości lub ewentualnych niewierności ${ }^{46}$. Przeniesienie części ducha Bożego z Mojżesza na starszych musiałoby zostać wówczas uznane za karę za niedostateczne zaufanie do Boga wyczerpanego stałymi kłótniami z ludem przywódcy. Taka interpretacja nie może zostać niczym uzasadniona. Warto tu dodać, że w Dz 6,3-4 znajduje się podobny quo ad sensum tekst wyboru diakonów spośród członków wspólnoty wierzących, „cieszących się dobrą sławą, pełnych Ducha i mądrości”, którzy mieli wspomagać apostołów w służbie na rzecz ubogich.

Liczba siedemdziesiąt może być odwołaniem do liczby przodków, którzy zeszli do Egiptu w czasach patriarchów ${ }^{47}$. Nie można jej jednak łączyć z Wj 24,1 w odniesieniu do tych, którzy mieli okazję udać się z Mojżeszem na szczyt Chorebu. Tamci bowiem ustanowieni zostali jedynie ad occasionem, podczas gdy obecnie chodzi o stały urząd wspomagający, co zbliża znacznie bardziej do wyboru rządców ludu nad tysiącem i setką ${ }^{48}$. Jest możliwe, że określona przez Boga liczba tych właśnie mężów dostąpiła obecnego zaszczytu, ponieważ podczas sprawowania urzędu odznaczali się cnotami sprawiedliwości, mądrości, rady i życiowego doświadczenia.

Nakaz przyprowadzenia ich przed namiot spotkania wyznacza właściwy cel całego przedsięwzięcia: by mogli być widziani przez cały lud, do którego świadomości dociera wielkość ich wyboru, wielkość darów, jakimi zostaną zaopatrzeni, a tym samym wielkość autorytetu i szacunku, jakimi mają się cieszyć jako współpracownicy Mojżesza. Bez tych umiejętności byliby bardziej przeszkodą dla Mojżesza niż jego pomocnikami. Mimo iż Mojżesz - doprowadzony do ostateczności zarówno oporem ludu, jak i poczuciem osamotnienia - przemawiał do Boga w sposób dość obcesowy, Bóg nie chce go rzeczywiście opuścić, lecz poprzez nową jakość spotkania z nim przede wszystkim uspokoić go i uodpornić na stres, jakiemu codziennie był poddany ${ }^{49}$. Można przypuszczać, że duch, którego przelał następnie Bóg z Mojżesza na stars zych ludu, był duchem mądrości, pobożności i odwagi. Nie działo się tak dlatego, jakoby Mojżeszowi

\footnotetext{
${ }^{45}$ Dlatego trzeba uznać, że byli to przede wszystkim mężowie mądrzy, doświadczeni i inteligentni, por. http://www.studylight.org/com/mhc-com/view.cgi?book=nu\&chapter=011 [dostęp 28.08.2012].

${ }_{46}$ Takie rozumienie mogą sugerować Mt 21,43 w odniesieniu do uczonych w Piśmie oraz Ap 3,11 z ostrzeżeniem, by nie dać sobie odebrać zasłużonej nagrody wiecznej.

${ }^{47}$ Por. Rdz 46,27; Wj 1,5 oraz Ez 8,11

${ }^{48}$ Chodzi o poradę Jetry daną Mojżeszowi w Wj 18, 21-22.25, a także Pwt 1,15; 16,18.

${ }^{49}$ Zwrot ירַדרתִ 'zejdę, zstąpię' oznacza przybliżenie się Boga do oznaczonego celu i wykonanie zamierzonej czynności, por. Lb 11,25; 12,5; Rdz 11,5; 18,21; Wj 19,11.20; 34,5, a także J 3,13. Z kolei rozmowa między Bogiem a Mojżeszem należy do specjalnego rodzaju kontaktów Boga z człowiekiem, które czynią obu tak bliskich sobie, por. Lb 12,8; Rdz 17,3.22; 18,20-22.33.
} 
brakowało już tego ducha lub by zrównać z nim star s z y ch $\mathrm{h}^{50}$. Oto z tego samego źródła, z którego moc swego ducha czerpał Mojżesz, otrzymali także starsi. Samo przelanie zaś nie umniejszyło w niczym wielkości tego, co posiadał wódz ludu ${ }^{51}$. Każdy z nich otrzymał zatem ducha Mojżeszowego proporcjonalnie do stopnia, w jakim wspomagał go w dźwiganiu ciężaru ludu. Mogli też otrzymać ducha proroczego dla ukazania swego boskiego powołania, ponieważ cała społeczność rządziła się prawami teokracji. W ten sposób trzeba podkreślić, że każdy, kogo Bóg przeznacza do jakiegokolwiek zadania, zostaje tym samym wyposażony w odpowiednie możliwości, środki i kwalifikacje. Wszystkie zaś dobre dary, jakie uzyskuje człowiek, pochodzą wyłącznie od Boga $(\mathrm{Jk} 1,17)^{52}$. Starsi stają się tym samym spadkobiercami ducha Mojżesza w sposób publiczny i oficjalny ${ }^{53}$.

Najlepszym nawiązaniem do problemu rezygnacyjnej czy wręcz kapitulacyjnej wobec zatwardziałości ludu postawy Mojżesza wydaje się ostrzeżenie skierowane przez Jezusa do uczniów podczas Jego pobytu w ogrodzie Oliwnym, na krótko przed męką. Wówczas to powiedział o słabości ciała pozostającego w opozycji do ducha ochoczego (Mt 26,41; Mk 14,38). Wnosić stąd można, że nawet wspaniałe porywy duchowe nie niwelują słabości i zmęczenia ciała, które może dać o sobie znać w różnych okolicznościach. „Ciało oznacza i wskazuje na słabość istoty ludzkiej [...] duch jest ochoczy, ale niekiedy nie potrafi wytrwać przy dobrych zamiarach" 54 . Można zatem przyjąć, że mimo wielkości swego ducha Mojżesz mógł rzeczywiście poczuć zmęczenie ponad swe siły fizyczne. To także ukazałoby sensowność całego postanowienia Bożego: Bóg przelewa część z ducha będącego na Mojżeszu na wybranych siedemdziesięciu star s z y ch I z ra e la, by ulżyć słabości jego ciała ${ }^{55}$. Tezę tę może też potwierdzać znany passus Łk 10,1-24 relacjonujący powołanie przez Jezusa siedemdziesięciu uczniów, których następnie wysłał, by głosili ewangelię tam, dokąd dopiero zamierzał przybyć. W szerszym jednak sensie mają oni głosić dobrą nowinę w imieniu Jezusa, tzn. po całym świecie, czyli tam, gdzie On sam nie przybędzie w sposób bezpośredni.

\footnotetext{
${ }^{50}$ Według Pwt 34,10 w historii Izraela nikt nigdy nie równał się Mojżeszowi.

${ }^{51}$ Por. http://www.studylight.org/com/geb/view.cgi?book=nu\&chapter=011\&verse=017 [dostęp 27.08.2012].

${ }^{52}$ Por. http://www.studylight.org/com/mhc-com/view.cgi?book=nu\&chapter=011 [dostęp 27. 08.2012].

${ }^{53}$ Por. pr. zb. Association Catholique Française pour l'Étude de la Bible (ACFEB), Le Pentateuque. Débats et recherches, s. 168.

${ }^{54}$ Por. A. Paciorek, Ewangelia wedlug świętego Mateusza, w: Nowy Komentarz Biblijny, t. 2: Nowy Testament, cz. 2, Częstochowa 2008, s. 576.

${ }^{55}$ Dla późniejszych rabinów izraelskich ten właśnie fakt stał się fundamentem tworzenia Sanhedrynu, por. http://www.studylight.org/com/acc/view.cgi?book=nu\&chapter=011 [dostęp 27.08.2012].
} 


\section{Na straży Bożych poleceń}

Dwa teksty biblijne ukazują pożyteczną funkcję stars zy zny Izraela. Pierwszym z nich jest Pwt 27,1:

Mojżesz razem ze starszymi Izraela wydat taki nakaz:

Zachowujcie całe to Prawo, które ja wam dziś oglaszam.

Wprowadzenie w kolejny rozdział Księgi Powtórzonego Prawa stanowi de facto dalszą część wcześniejszego zbioru nakazów o charakterze generalnym, zawartego w 26,16-19. Wyraża się on w zwrotach typu: wykonaj prawa i nakazy - strzeż i pełnij z całego serca i duszy (w. 16) - chodź Jego drogami - strzeż praw i poleceń - słuchaj Jego głosu (w. 17) - zachowuj Jego wszystkie polecenia (w. 18). Wezwania te przeplecione zostały obietnicami ze strony Boga, zapowiedzianymi przez Mojżesza: Pan będzie dla ciebie Bogiem (w. 17) - być ludem stanowiącym szczególną Jego własność (w. 18) - On cię wywyższy we czci, sławie i wspaniałości ponad wszystkie narody - abyś był ludem świętym dla Pana, Boga twego (w. 19). Są to niezwykle istotne uzasadnienia wierności skierowane ku przyszłości narodu, która całkowicie uzależniona zostaje od wierności żądanej już obecnie i mającej się wypełniać w codziennym życiu Izraelitów. Z kolei dalsza część tekstu biblijnego mówi o utworzeniu trwałego, materialnego znaku zawartego przymierza już po przejściu Jordanu i zajęciu Ziemi Obiecanej ${ }^{56}$. Mają nim być wielkie, pobielone wapnem kamienie $\mathrm{z}$ wypisanym na nich prawem Mojżeszowym, które mają stać na świadectwo przymierza zawartego między Bogiem a Jego ludem. Ich drugą funkcją ma być stałe przypominanie ludowi o wierności, którą obiecał swemu Bogu (27,2-8).

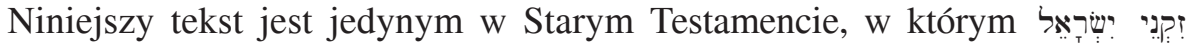

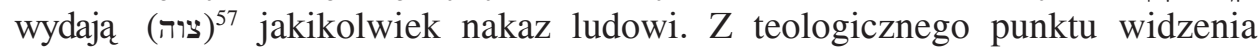
wzmianka ta jest bardzo ważna. Ponieważ Mojżesz zbliża się już do końca swojego życia, właśnie oni przejmą wraz z jego następca, Jozuem, obowiązek pouczania ludu i dbania o jego wytrwanie w wierności prawu ${ }^{58}$. Można ów cytat uznać zatem za swoistą rekapitulację ich pozytywnej roli w całym procesie wychowywania ludu do przestrzegania prawa Mojżeszowego i przejaw uznania ze strony

\footnotetext{
${ }^{56}$ Pobyt na niej jest ściśle uwarunkowany wiernością prawu Bożemu, por. G. Vanhoomissen, En commençant par Moüse, dz. cyt., s. 216-221.

${ }^{57} \mathrm{~W}$ tekście biblijnym aż 20 razy Mojżesz wydaje ludowi jakieś rozporządzenia lub wspomina się o tej jego roli, por. Wj 16,24; 36,6; Kpł 9,5.21; Lb 34,13; 36,5; Pwt 27,11; 31,10.25; Joz 1,7; 4,10; 8,31.33.35; 11,12.15; $2 \mathrm{Krl} 18,12 ; 1 \mathrm{Krn} 6,34 ; 15,15$.

${ }^{58}$ Por. http://www.godrules.net/library/delitzsch/26delitzsch_b0.htm [dostęp 28.08.2012]. Być może ów nakaz należy wiązać ze spowodowaną śmiercią nieobecnością Mojżesza podczas ceremonii odnowienia przymierza na górze Ebal po wejściu do Ziemi Obiecanej (Pwt 27,4.13), por. D.L. Christensen, Deuteronomy 21:10-34:12, Word Biblical Commentary, vol. 6B, Dallas 2002, s. 653.
} 
autora biblijnego dla ich postawy w całej epoce wyjścia, ponieważ zawsze stali po stronie wodza ludu i wspomagali go w trudach jego misji ${ }^{59}$. Natomiast niezbyt precyzyjnie można określić, czy s t a r s i rzeczywiście mieli prawo wydawać polecenia, czy jedynie ogłaszać ludowi słowa Mojżesza. Z uwagi na dotychczasowe całkowite podporządkowanie przywódcy ludu i brak własnej inicjatywy ich zadanie należy rozumieć raczej $\mathrm{w}$ tym drugim znaczeniu. Być może także ów dodatek należy skonfrontować z w. 9-10, w których Mojżesz ponownie wydaje dyrektywę przestrzegania prawa, lecz tym razem wespół z kapłanami lewickimi, czyli duchowymi przewodnikami ludu. Stąd obecność st ars zy ch I zraela, jako przywódców świeckich, może być poczytana jako dopełnienie całości życia ludu: przykazania mają być przestrzegane zarówno w relacji do Boga, jak i do każdego członka społeczności, tak w sposób duchowy, wewnętrzny, jak i widzialny, zewnętrzny, czyli w relacjach międzyludzkich. Prawo bowiem nie działa jedynie na gruncie religijnym, lecz także moralnym i społecznym. Żadna więc płaszczyzna życia pobożnego Izraelity nie może być wyjęta spod konieczności podporządkowania się prawu Bożemu ${ }^{60}$.

Drugim ważnym tekstem obrazującym tę problematykę jest Pwt 31,9:

I napisat Mojżesz to Prawo, dat je kapłanom, synom Lewiego, noszacym Arke Przymierza Pańskiego

$i$ wszystkim starszym Izraela.

Po nadaniu inwestytury swemu następcy, Jozuemu (w. 1-8) , $^{61}$, Mojżesz dokonuje promulgacji prawa (w. 9-13), które co siedem lat w Święto Namiotów ma być odczytywane całemu ludowi w miejscu wybranym sobie przez Pana na spoczynek (w. 10-11). Celem tej lektury nie jest jedynie zwyczajowe przypominanie poszczególnych przepisów, lecz przede wszystkim umocnienie się w postawie bezwarunkowej im wierności, co wyraża się dwoma leksykalnymi rdzeniami natury generalizującej: ירא, 'bać się' oraz שמר, 'przestrzegać, strzec' (w. 12) Skutkiem tego ma być także nauczenie przyszłych pokoleń wierności, co zrodzi w nich tę samą postawę posłuszeństwa przepisom oraz bojaźni Boga po wszystkie dni pobytu w Ziemi Obiecanej (w. 13). Dalsze stwierdzenia dotyczące poprzedniego tekstu Pwt 27,1 znajdują pełne potwierdzenie także w cytacie obec-

${ }_{59}$ Por. http://www.studylight.org/com/geb/view.cgi?book=de\&chapter $=027 \&$ verse $=001$ [dostęp 28.08.2012].

${ }^{60}$ Por. http://www.studylight.org/com/mhc-com/view.cgi?book=de\&chapter=027 [dostęp 28.08.2012].

${ }^{61}$ Jako sukcesor wodza z pełnymi jego prerogatywami, por. G. Vanhoomissen, En commençant par Moïse, dz. cyt., s. 229-232.

${ }^{62}$ Znakomite opracowanie całościowe tej tematyki, por. J. L'Hour, La morale de l'Alliance, Paris 1985, s. 53-69. 
nym. To bowiem, co nakazywali ludowi wcześniej, zostaje obecnie złożone $\mathrm{w}$ formie pisemnej w ich ręce, by mogli przejąć wraz z Jozuem dalszy obowiązek pouczania ludu i walki o jego wytrwanie w wierności prawu ${ }^{63}$. Z tej właśnie racji zostali zobowiązani do posiadania egzemplarza, na którym mogą od tej pory opierać swoje nauczanie i wymagania odnoszące się do życia duchowego, moralnego i społecznego każdego członka zgromadzenia Pana. Ta interpretacja nie jest jednak jedyną możliwą, ponieważ w. 9 można rozumieć także w ten sposób, że jedyny egzemplarz Księgi Prawa został dany bezpośrednio wyłącznie kapłanom, by schowali go do Arki Przymierza. Tymczasem nie tylko oni mieli mieć do niej dostęp, lecz - za ich pośrednictwem - także st a rs i ludu ${ }^{64}$, by dbać nie tylko o jej przechowywanie, lecz systematyczne odczytywanie ludowi. Prawo bowiem zamknięte $\mathrm{w}$ Arce nie służy niczyjemu interesowi, jeśli nie jest z nim zapoznawany ten, który stał się jego najważniejszym adresatem, mianowicie cały lud 65 .

Możliwe natomiast, że - według tradycji zwłaszcza żydowskiej - Mojżesz spisał dwie kopie tekstu prawa. Pierwsza została przekazana właśnie kapłanom i starszym, by w imieniu całego ludu otrzymali na własność fundament przymierza. Druga zaś kopia, jak zaświadcza Pwt 31,26, znalazła się w Arce Przymierza jako świadectwo dla Boga, który zyskiwał tym samym swoiste prawo wymagania od ludu wierności na podstawie tego, do czego lud się zobowiązał, a co zostało zapisane przez jego wodza. W ten sposób wszystkie kolejne pokolenia unikną niebezpieczeństwa zapomnienia fundamentów swej egzystencji, a tym samym zostały wprzęgnięte w nakaz wierności Bożym poleceniom aż do końca czasów ${ }^{66}$. Z kolei lud zyskiwał pewność, że Bóg nie zapomni o własnych zobowiązaniach wobec niego, że będzie go zawsze wspierał w najróżniejszych sytuacjach życiowych $^{67}$. Niektórzy egzegeci przypuszczaja, że oddanie Księgi Prawa kapłanom zobowiązuje ich do nauczania wszystkiego, czego domaga się Bóg a do czego

${ }^{63}$ Por. D.L. Christensen, Deuteronomy 21:10-34:12, dz. cyt., s. 765.

${ }^{64}$ Ponieważ nikomu poza kapłanami nie wolno było dotykać Arki Przymierza, zgodnie z surowym zakazem Bożym.

${ }^{65}$ Por. http://www.godrules.net/library/delitzsch/26delitzsch_b0.htm [dostęp 28.08.2012]. To połączenie obu funkcji: sakralnej i społecznej, zyskało w Nowym Testamencie o wiele mocniejszy status, o czym szerzej piszą: T. Hergesel i E. Pasionek, „Arcykaptani i starsi” (Mt 27,20), w: Oto idę. Księga pamiatkowa dla Biskupa Profesora Jana Bernarda Szlagi w 65. rocznice urodzin, red. W. Chrostowski, Warszawa 2005, s. 190-199 oraz M. Mikołajczak, Świadectwo Jezusa w światyni jerozolimskiej wobec sprzeciwu starszych (Dz 4-6), w: Stowo jest prawdq. Księga pamiatkowa dla Księdza Profesora Stanisława Mędali CM w 65. rocznicę urodzin, red. W. Chrostowski, Warszawa 2000, s. 253-263.

${ }^{66}$ Por. http://www.studylight.org/com/mhc-com/view.cgi?book=de\&chapter=031 [dostęp 28. 08.2012].

${ }^{67}$ Praktykę tę, jakkolwiek w odniesieniu do zapisów kontraktu handlowego, prezentuje Jr 32,12-14. Por. także http://www.studylight.org/com/acc/view.cgi?book=de\&chapter=031 [dostęp 28.08.2012]. 
lud się zobowiązał, zaś do star s zy c h, jako przedstawicieli władzy cywilnej, należy egzekwowanie wierności prawu poprzez dbałość o zachowanie samego tekstu sakralnego i jego powtarzanie wspólnotowe lub indywidualne ${ }^{68}$. Można także sądzić, że kapłani zwrócili uwagę przede wszystkim na prawodawstwo kultyczne i moralne, podczas gdy st a r s z y z n a na prawodawstwo społeczne ${ }^{69}$. W ten sposób podkreślona zostaje jej rola jako grupy osób, które stały się odpowiedzialne za przekaz prawa Mojżeszowego. Ich rola wzrośnie ogromnie w epoce powygnaniowej, gdy wraz z kapłanami właśnie na nie spadnie zadanie organizacji całości życia religijnego narodu będącego w rozsypce $\mathrm{z}$ racji braku świątyni ${ }^{70}$.

Podsumowując zebrane wiadomości, zauważyć można następujące cechy biblijnej starszyzny Izraela czasów Mojżesza:

a) samodzielnie nie podejmuje ona żadnych własnych inicjatyw;

b) pozostaje bezwzględnie wierna przywódcy ludu, wspierając go w działaniach dla dobra społeczności;

c) zostaje wybrana przez zgromadzenie do wypełnienia określonych zadań, zwłaszcza służących porządkowaniu życia wewnątrz społeczności i tym samym nadających jej właściwy kierunek rozwoju (Wj 3,18);

d) jej rola przewodnia może rozciagnąc się także na funkcje rytualne, które ma wykonywać jako pierwsza w społeczności, by następnie uświadomić wartość tych funkcji wszystkim członkom wspólnoty (Wj 12,10);

e) jako reprezentant ludu wobec Boga w konkretnej sytuacji grzechu, w imieniu tegoż ludu pragnie błagać o przebaczenie za jego występki (Joz $7,6)$;

f) poprzez własne bezdyskusyjne posłuszeństwo staje się gwarantem odwagi reszty w trudnych okolicznościach (Joz 8,10), lecz także świadczy o wartości wszelkich Bożych nakazów skierowanych do ludu, zwłaszcza w sytuacjach oporu i buntu (Wj 17,5.6; Lb 16,25);

g) jako uczestnik wyjątkowych wydarzeń staje się łącznikiem między świeckością społeczności a świętością Boga (Wj 18,12; 24,1.9);

h) obdarowana specjalnymi charyzmatami współpracuje bezwarunkowo z wodzem ludu dla dobra społeczności (Lb 11,16-17.25.30);

i) stoi na straży Bożego prawa, zwłaszcza w przypadku aplikowania go do konkretnych warunków życia społeczności (Pwt 27,1; 31,9).

${ }^{68}$ Por. http://www.studylight.org/com/jfb/view.cgi?book=de\&chapter=031 [dostęp 28.08.2012].

${ }^{69}$ Por. http://www.studylight.org/com/geb/view.cgi?book=de\&chapter=031\&verse=009 [dostęp 28.08.2012].

${ }^{70}$ Por. J.L. Ska, Introduction à la lecture du Pentateuque, dz. cyt., s. 324; N. Lohfink, Die Ältesten Israels und der Bund: Zur Zusammenhang von Dtn 5,23; 26,17-19; 27,1.9f. und 31,9, „Biblische Notizen” 67 (1993), s. 26-41. 
Z powyższego podsumowania wnosić można, że funkcje starszyzny I zra e la były dość rozległe, a przez to jej społeczna i religijna rola w zgromadzeniu wierzących Izraelitów o wiele większa, niż można by przypuszczać.

\title{
What is the Role of the Elders of Israel in Texts Depicting the Epoch of Moses?
}

\begin{abstract}
The article presents the importance attributed to the term "the elders of Israel" by biblical authors. Exegesis of the relevant passages reveals in this expression some kind of social elite, separated from the rest of the common crowd, which, however, does not undertake any initiatives on its own, remaining absolutely faithful to the leader of the people and supporting him in action for the good of the community. Elected by the congregation for the purpose of organizing life within the community they also perform some ritual functions. As representatives of a sinful people before God, on behalf of that people "the elders of Israel" beg forgiveness for transgressions and by unquestionable obedience become guarantors of Israel's courage in difficult circumstances. In situations of rebellion they also, as guardians of God's law, manifest the value of all of God's commandments. As participants of exceptional events they become a link between the secular community and the holiness of God.
\end{abstract}

\section{Keywords}

The Bible, Old Testament, the elders of Israel, Moses, Joshua

\section{Słowa kluczowe}

Biblia, Stary Testament, starsi Izraela, Mojżesz, Jozue 